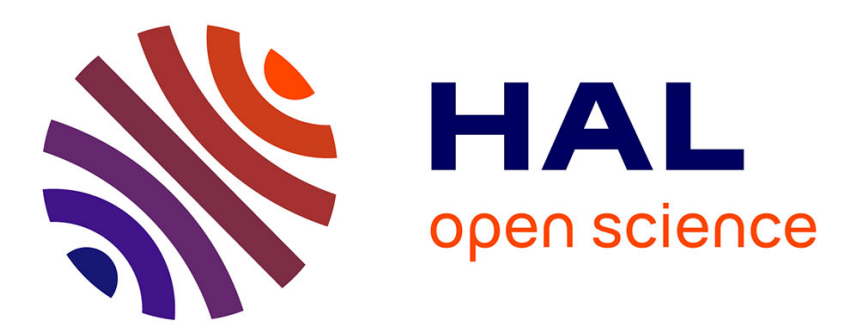

\title{
Stock Market Capitalization and Financial Integration in the Asia Pacific Region
}

Hui-Boon Tan, Eng Tuck Cheah, Johnnie Johnson, Ming-Chien Sung, Chong Hin Chuah

\section{- To cite this version:}

Hui-Boon Tan, Eng Tuck Cheah, Johnnie Johnson, Ming-Chien Sung, Chong Hin Chuah. Stock Market Capitalization and Financial Integration in the Asia Pacific Region. Applied Economics, 2011, pp.1. 10.1080/00036846.2011.556593 . hal-00684298

\section{HAL Id: hal-00684298 \\ https://hal.science/hal-00684298}

Submitted on 1 Apr 2012

HAL is a multi-disciplinary open access archive for the deposit and dissemination of scientific research documents, whether they are published or not. The documents may come from teaching and research institutions in France or abroad, or from public or private research centers.
L'archive ouverte pluridisciplinaire HAL, est destinée au dépôt et à la diffusion de documents scientifiques de niveau recherche, publiés ou non, émanant des établissements d'enseignement et de recherche français ou étrangers, des laboratoires publics ou privés. 


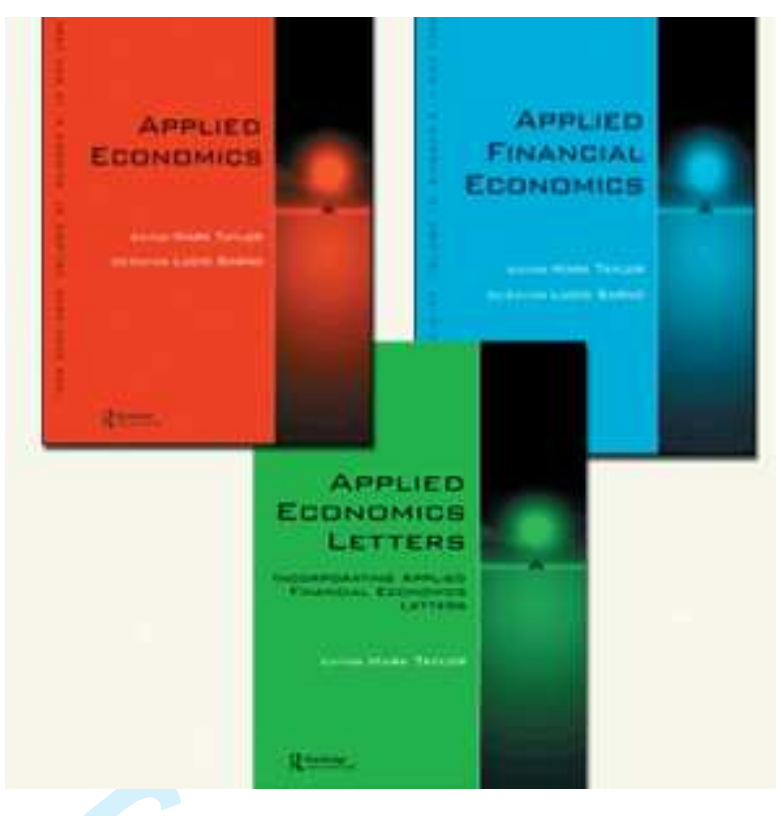

\section{Stock Market Capitalization and Financial Integration in the Asia Pacific Region}

\begin{tabular}{|r|l|}
\hline Journal: & Applied Economics \\
\hline Manuscript ID: & APE-2009-0302.R1 \\
\hline Journal Selection: & Applied Economics \\
\hline Author: & 10-Dec-2010 \\
\hline Complete List of Authors: & $\begin{array}{l}\text { Tan, Hui-Boon; University of Nottingham Malaysia Campus, } \\
\text { Nottingham University Business School } \\
\text { Cheah, Eng Tuck; University of Southampton, School of } \\
\text { Management } \\
\text { Johnson, Johnnie; University of Southampton, Centre for Risk } \\
\text { Research, School of Management } \\
\text { Sung, Ming-Chien; University of Southampton, School of } \\
\text { Management } \\
\text { Chuah, Chong Hin; EDS MSC }\end{array}$ \\
\hline JEL Code: & $\begin{array}{l}\text { N25 - Asia including Middle East < N2 - Financial Markets and } \\
\text { Institutions < N - Economic History, G15 - International Financial } \\
\text { Markets < G1 - General Financial Markets < G - Financial } \\
\text { Economics, F36 - Financial Aspects of Economic Integration < F3 - } \\
\text { International Finance < F - International Economics, C22 - Time- } \\
\text { Series Models < C2 - Econometric Methods: Single Equation Models }\end{array}$ \\
\hline
\end{tabular}


Keywords: Stock Market Capitalization, Financial Integration, Cointegration, Granger Causality, Speed of Adjustment

\section{SCHOLARONE ${ }^{m}$ Manuscripts}




\title{
STOCK MARKET CAPITALIZATION AND FINANCIAL INTEGRATION IN THE ASIA PACIFIC REGION
}

\author{
Hui-Boon Tan ${ }^{a}$,Eng-Tuck Cheah*b, Johnnie E.V.Johnson ${ }^{b}$, Ming-ChienSung ${ }^{b}$,Chong-HinChuah ${ }^{c}$
}

aNottingham University Business School, Faculty of Social Sciences, Nottingham University Malaysia Campus, JalanBroga, 43500 Semenyih, Selangor DarulEhsan, Malaysia.

${ }^{* b}$ School of Management, University of Southampton,Highfield Campus, Southampton, SO17 1BJ, United Kingdom.

'EDS MSC (Malaysia), Block 3502, Enterprise 2, JalanTeknokrat 5, 63000 Cyberjaya, Selangor DarulEhsan, Malaysia.

\begin{abstract}
The stock market capitalization (SMC) of a country, defined as the aggregated market value equity of companies in the respective equity market, is commonly used to measure the widening and deepening of stock market activity. SMC also influences economic growth predictions and public consensus concerning the value of the stock market. However, no previous work has examined the role this variable plays in the process of financial integration. This paper provides an argument for the use of SMC as a means of deciding which countries are acting as leaders in creating a fully integrated equity market in the Asia Pacific region. A total of twelve countries in the Asia Pacific region were divided into 'Emerging Market' and 'Advanced Market' equity blocks. We examine the relative size of the speed of adjustments derived from the error correction models following the Engle-Granger two-step procedure framework and apply the Granger causality test. The results suggest that Hong Kong SAR possesses the necessary credentials to act as market leader. In fact, Hong Kong SAR appears to be the only contender for market leader of both the 'Emerging Market' and 'Advanced Market' equity blocks.
\end{abstract}




\section{STOCK MARKET CAPITALIZATION AND FINANCIAL} INTEGRATION IN THE ASIA PACIFIC REGION

\section{INTRODUCTION}

Arguably, the significant economic growth experienced by Asia Pacific countries following financial integration (prior to the Asian financial crisis) arose from an inflow of equity investments into the emerging markets. Financial integration increased opportunities for cross-border investment and have led portfolio managers to resort to using a country's total stock market capitalization (SMC) as a criterion for highlighting potential investment opportunities. For example, Freeman (2000) argued that most Asian Pacific equity markets, with the exceptions of Malaysia and Singapore, are not considered by fund managers due to their relatively small size. As policy makers in the Asia Pacific region were aware of the fact that in order to attract foreign equity market participants to invest in their respective countries, efforts to widen and deepen their respective equity markets were undertaken. Consequently, a larger equity market (higher SMC) reflects a more mature and developed equity market.Therefore, in order to enjoy the benefits from a unified group of equity markets, governments in the Asia Pacific region have initiated financial integration processes to remove financial barriers, such as capital control measures. This appears to occur even though an integrated financial market implies that a financial crisis or post-crisis recovery experienced in one country is likely to quickly transmit to others (Click \& Plummer, 2005).

A country's SMC, the aggregated market value equity of companies in the respective equity market, has traditionally been used as a measure of stock market activity (Torre et al, 2006; Rajan\&Zingales, 1998). It is also used to reflect a country's level of credit and economic growth, in anticipation of future growth in the equity market. This arises because equity 
markets capitalize the present value of future growth opportunities (Rajan\&Zingales, 1998). SMC is also used by investors as a measure of public consensus and confidence in the value of an equity market. However, no prior studies have used SMC to measure the degree of financial integration among financial markets within an international setting.

This paper is the first to use SMC to determine the potential leader in the Asia Pacific region's financial integration process. The identification of a leader in this process is important since it can help to establish a properly coordinated policy for removing trade and financial barriers, to allow for wider investor participation. In addition, in the event of a financial or economic crisis, the leader can be looked upon to provide the necessary policy recommendations and the smooth execution of these policies to ensure a return to stability.

The paper has two objectives: First, to use SMC to provide empirical evidence concerning the dynamics of financial integration in the Asia Pacific region. Second, to identify the potential leader in the region; that equity market which is likely to propel the region into the next stage of financial integration. These objectives are achieved by dividing the twelve countries in the region into an "Emerging" and "Advanced" Markets Blocks (EMB and AMB). Cointegration analysis is then conducted between the SMC of each country and the equity blocks. We perform a Granger causality test to explore whether the SMC of a country Granger-causes the growth in SMC of the equity blocks. An individual country is identified as a potential leader in the financial integration process in the Asia Pacific region if it is an attractor (one which has a larger absolute speed of adjustment coefficient estimate than the absolute speed of adjustment coefficient estimate of the respective equity block) and Granger-causes the growth in the respective equity blocks. Our results reveal that Hong Kong SAR is the most likely leader in the region. 


\section{FINANCIAL INTEGRATION}

Previous work on financial integration has focused on developed countries (Arshanapalli\&Doukas, 1993). Research on financial integration across the Asian economies has produced contradictory conclusions (Click \& Plummer, 2005)or, at best, mixed conclusions (Cavoli et al., 2004). For example, Ng (2002) found no cointegrating relationship among ASEAN-5 equity markets, whereas, Click \& Plummer (2005) found cointegrating relationships between ASEAN-5 equity markets and Daly (2003) reports mixed findings. However, these studies take a partial and abstracted view of the financial integration process. Finally, some studies have examined the degrees of financial integration in the region, without identifying a leader with the potential to spearhead the process. Consequently, it is now timely to examine which country is likely to lead in the next phase of the financial integration process in the Asia Pacific region.

In this study, we use SMC to measure the degree of financial interdependence in Asia Pacific equity markets and to identify a potential leader to bring these distinct equity markets into a larger, more unified equity block. This approach is motivated by the fact that the use of equity market size in general, and SMC in particular, has been the subject of much recent debate (e.g., Desai \&Dharmapala, 2008). 


\section{DATA AND METHODOLOGY}

\section{Data Description}

The data employed here consists of the daily value-weighted market indices (provided by Bloomberg) for 12 countries in the Asia Pacific region, for the period 22 September 2003 to 29 October 2007. This period was chosen because several stock markets in this region are relatively new and it helped ensure consistency in the available data across the markets under investigation. The data was converted to weekly values to standardize the differences in trading days used by different countries in the region. This resulted in a total of 215 observations. The use of weekly data prevented potential micro-structure biases, such as thin trading, bid-ask spread and non-trading (often associated with emerging equity markets), from contaminating the empirical results (Ahmad et al., 2003). The region's equity markets were classified as EMB(China, Indonesia, Korea, Malaysia, Philippines, Taiwan and Thailand) or AMB(Japanese, Hong Kong SAR, Australian, Singaporean and New Zealand), based on Standard and Poors/IFCG classification.

Summary statistics for the data are presented in Table 1. The variables EMB and AMB are simple arithmetic averages for the variables associated with the constituent equity markets in these blocks.

\section{[Insert Table 1 here]}

It is clear from the data presented in Table 1 that the three largest equity markets, in terms of the mean SMC (during the study period) within the EMB, are China, Korea and Taiwan and within the AMB are Japan, Hong Kong SAR and Australia. In addition, it is worth pointing out that the weekly average SMC value for Japan from 2003 to 2007 dwarfs that of the remaining equity markets in the Asia Pacific region. 


\section{Cointegration and Speed of Adjustment}

In order to identify the Asia Pacific region's potential leading equity market, two criteria were applied: First, the equity market must act as an "attractor equity market"; i.e. the equity market must assume a stronger role in pulling the natural logarithm of the SMC of other equity markets towards the long run equilibrium path. Second, the lagged SMC growth rates of the equity market must Granger-cause the SMC growth rate of the equity block in question (and not vice versa).

We employed the well-established two-step cointegration procedure, introduced by Engle and Granger (1987). In particular, we employed the unrestricted dynamic modeling approach so that the estimates derived for the long-run relationship are unbiased using the appropriate $t$ - and $F$-statistics. Since the number of variables in the model does not exceed two, there is no justification for employing the Johansen (1988) approach to test for cointegration. To test for stationarity in the weekly series, the Augmented Dickey-Fuller (ADF) and Phillips-Perron (PP) were used.

Before developing the respective error correction models, it is essential to determine whether the stochastic trends in the natural logarithm of the weekly SMC variable for the 12 countries' equity markets and the two equity blocks (that contained the unit root in the level) have a long-run relationship under the Engle-Granger two-step procedure. This is accomplished by regressing a non-stationary level dependent variable against a nonstationary level independent variable. The resulting error of the cointegrating regression is then subjected to stationarity testing in a second step. The cointegrating equations are of the form: 


$$
\begin{aligned}
& y_{t}=\gamma_{0}+\gamma_{1} x_{t}+\varepsilon_{1 t} \\
& x_{t}=\kappa_{0}+\kappa_{1} y_{t}+\varepsilon_{2 t}
\end{aligned}
$$

where $y_{t}$ measures the natural logarithm of week $t$ 's SMC of an individual equity market, $x_{t}$ measures the natural logarithm of week $t^{\prime}$ S SMC of the respective blocks (i.e. EMB and AMB); $\gamma_{0}$ and $\kappa_{0}$ are the intercepts while $\gamma_{1}$, and $\kappa_{1}$ are the long-run relationship parameters and $\varepsilon_{1 t}$ and $\varepsilon_{2 t}$ are the error terms to be tested for stationarity.

The Granger Representation Theorem (Engle \& Granger, 1987) indicates that if two (or more) variables are linked to form an equilibrium relationship spanning the long-run, or are cointegrated, then there exists an error-correction representation of the data; even though the series themselves may contain stochastic trends. In essence, the theorem safeguards the error-correction model from the problem of spurious regression.Therefore, if $y_{t}$ and $x_{t}$ are I(1), the following error-correction models can be established, respectively, as:

$$
\begin{aligned}
& \lambda(L) \Delta y_{t}=\alpha_{1} \varepsilon_{1 t-1}+\eta(L) \Delta x_{t-1}+u_{1 t} \\
& \pi(L) \Delta x_{t}=\alpha_{2} \varepsilon_{2 t-1}+\varphi(L) \Delta y_{t-1}+u_{2 t}
\end{aligned}
$$

where $\lambda(L), \eta(L), \pi(L)$ and $\varphi(L)$ are polynomials in the lag operator $L$, given as $\lambda(L)=1-\lambda_{1} L^{1}-\ldots-\lambda_{p} L^{p}, \eta(L)=\eta_{0}-\eta_{1} L^{1}-\ldots-\eta_{q+1} L^{q+1}, \pi(L)=1-\pi_{1} L^{1}-\ldots-\pi_{p} L^{p}$, $\varphi(L)=\varphi_{0}-\varphi_{1} L^{1}-\ldots-\varphi_{q+1} L^{q+1}$.At least one of the speed of adjustments coefficients, $\alpha_{1}$ or $\alpha_{2}$, is significantly different from zero and $\varepsilon_{1 t-1}$ and $\varepsilon_{2 t-1}$ are the error-correction terms (ECT) in the model. The formulation in Equation 2 above allows us to estimate the corresponding ECT coefficients, which indicate the strength and speed of adjustment towards long-run equilibrium. These speed of adjustment values measure the proportion of last period's equilibrium error that is corrected by the narrowing of the distance of the 
system in the current period from its equilibrium. In other words, the speed of adjustment is a mechanism which enables the system to correct the disequilibrium in the system quickly, by forcing the system to return to its long-run steady-state growth path.

Two important properties of the speed of adjustment coefficients are worth mentioning: First, $\alpha_{1}$ measures the speed that the natural logarithm of the SMC of an individual equity market adjusts to the equilibrium path. This, in turn, is determined by the natural logarithm of the SMC of the equity block. In this case, the equity block appears to be the force of attraction to the individual equity market. Second, the speed of adjustment parameter will take an absolute value between zero and one; a value close to zero indicates a tendency for the system to fail to correct the disequilibrium to its long-run equilibrium, and a value close to one indicates a tendency for the system to narrow the distance (in the current period) from its long-run equilibrium path. Similarly, $\alpha_{2}$ captures the speed that the natural logarithm of the SMC of the equity block corrects towards the long-run equilibrium path (which is determined by thenatural logarithm of the SMC of the individual equity market). In this latter case, the individual equity market acts as the attractor. By observing which of the absolute ECTs from Equation 2, $\left|\alpha_{1}\right|$ and $\left|\alpha_{2}\right|$, has the larger value, we can identify whether the individual equity market or the respective equity block is acting as the attractor to the underlying long-run equilibrium path.

\section{Error-Correction and Granger-Causality}

The error-correction model formulation also provides a means of investigating the short-run causal impact between the growth rate of the SMC of the individual stock market and the respective equity block, and vice versa. Granger (1988) maintained that long-run equilibrium is a concern for cointegration, while short-run forecastability is the concern of Granger causality. In our study, the joint significance testing of the coefficients for lagged 
differences of the independent variable $\left(H_{0}: \eta_{0}=\ldots=\eta_{q+1}=0\right)$ implies the causality running from $\Delta x_{t}$ to $\Delta y_{t}$. Similarly, in order to test the causality running from $\Delta y_{t}$ to $\Delta x_{t}$, we can jointly test for $\left(H_{0}: \varphi_{0}=\ldots=\varphi_{q+1}=0\right)$. The chosen, optimal number of lags for $p$ and $q$ are based on AIC, following the sequential procedure outlined by Hsiao (1979a, b). This procedure requires the addition of $q$ lags to the error correction model, once the number of $p$ lags, which minimizes the AIC, has been chosen.

\section{RESULTS AND DISCUSSION}

\section{Results}

The results of the unit root tests using the ADF and PP tests are reported in Table 2. The usual information based rule, namely the AIC, is used to determine the optimal lag length ${ }^{1}$.

\section{[Insert Table 2 here]}

Results presented in Table 2 suggest that the natural logarithm transformed weekly SMC variable is not stationary in its level form. These series appear to be stationary for all countries in the Asia Pacific region after taking the first difference (growth rate in SMC). The same is true for the EMB and AMB.

\section{[Insert Table 3, 4, 5 and 6 here]}

The results of the Engle-Granger two-step cointegration test, presented in Table 3, reveal the existence of cointegration relationships between the individual equity markets against the two equity blocks. The adequacy of the cointegration model used this study is confirmed by

${ }^{1}$ For a detailed discussion of the guidelines for determining the optimal lags for inclusion in the unit root tests, refer to Ng and Perron (1995). 
the statistically significant results of the ADF test on the residuals on each equation in Equation 1(as presented in Table 3). The results presented in the last columns of Tables 4 and 5 show the pair-wise estimated coefficients of the speed of adjustment of individual stock markets against the long-run equilibrium path (as determined by the respective equity block, and vice versa). The adequacy of the error correction models is confirmed by the negative and statistically significant ECT coefficients, which are presented as the estimated speed of adjustment coefficients in the last columns in Tables 4 and 5. From the results presented in Panel A of Table 5, it is also clear that, with the exception of China, the speed of adjustment estimates of all individual equity markets in the EMB are statistically significant at the 1 percent level. For China, the natural logarithm of SMC is correcting towards the equilibrium long-run path (which is determined by the EMB) but there is no evidence of the natural logarithm of SMC of EMB correcting towards the equilibrium long-run path determined by China. This is clear as the speed of adjustment estimate $\left|\alpha_{2}\right|$ is not statistically significant. All of the estimates for the speed of adjustment pairs (shown in Panel B, Table 5) are statistically significant at 1 percent for the AMB. It appears that the two equity blocks are also adjusting to the long-run equilibrium path (results are significant at the 1 percent; see Panel C, Table 4).

Comparing the relative sizes of the absolute ECTs, we generate a list of attractor markets (shown in second column, Table 6.); in particular, Korea, Hong Kong SAR and Singapore for EMB and China, Malaysia, Hong Kong SAR, Australia, Singapore and New Zealand for AMB. As indicated above, the results from this test only satisfy the first criterionfor identifying the leader. It is clear that the natural logarithm of SMC of the equity blocks also needs to correct towards the natural logarithm of SMC of the individual equity market for it to provide the leadership role. Our results clearly show that Hong Kong SAR and Singapore act as the collective leaders of this Asia Pacific region, as the natural logarithm of SMC of the two equity blocks are correcting towards the natural logarithm of SMC of Hong Kong SAR and Singapore. 
The results from a Wald test of jointly testing for all lagged independent variables are reported in Tables 4 and 5. The direction of causality is summarized in column 3 of Table 6. Allowing for bi-directional causality, the SMC growth rate in Indonesia appears to be causing (significant at the 1 percent level) the growth in the SMC of the EMB in the Granger sense (see Panel A of Table 4). In addition, the results suggest that the SMC growth rate of Hong Kong SAR Granger-cause the growth in the EMB (see Panel B, Table 4). By comparing the results for the EMB and $\mathrm{AMB}$, the SMC growth rate of EMB appears to be Granger-causing the growth in SMC in AMB (see Panel C of Table 4). The results also indicate (at the 1 percent level of significance) that the SMC growth rates of all emerging equity markets, with the exception of Korea, are Granger causing the growth in the AMB (see Panel A, Table 5). In addition, with the exception of Japan and New Zealand, the growth rate of SMC of the individual advanced equity markets are Granger causing the growth in the AMB (see Panel B of Table 5).

When the two leadership conditions are jointly considered (i.e. equity market must be an attractor and must Granger-cause the growth in the SMC of the respective equity block), Hong Kong SAR appears to be the overall leader in the Asia Pacific region, as it fulfills both conditions in both equity blocks. China, Malaysia, Hong Kong SAR, Australia and Singapore are all identified as possible potential leadersforthe AMB. However, Malaysia may be eliminated from this list, since the relative absolute values of its speed of adjustment derived from the pair-wise error correction model are close. If only uni-directional causality is allowed, then only China and Hong Kong SAR emerge as the potential leaders for the AMB (see last column, Table 6).

\section{Implications of Study}




\section{CONCLUSION}

We have argued that the size of a particular equity market plays an important role in deciding the status of a leader within a region and this study tests for financial integration in the Asia Pacific region, using the Engle-Granger two-step approach on the SMC growth rate. Our results show that the size of equity markets, measured by their SMC growth rates, matter in determining potential leaders within the Asia Pacific region. Such countries can take an important role in spearheading the region into a full-fledged and integrated capital market block. Our results suggest Hong Kong SAR has the potential totake a leading role in 
the next phase of financial integration in this region.However, whether or not Hong Kong SAR takes up this challenge remains to be seen.

\section{ACKNOWLEDGEMENTS}

The authors would like to thank Jean-Yves Pitarakis, Jan Podivinsky and TaufiqChoudhury of University of Southampton for helpful comments and suggests.

\section{REFERENCES}

Ahmad, Z.B., Sarmidi, T. \& Tan, H.B. (2003) Dynamic linkages of Asian stock markets, Journal of Asia Pacific Economy, 8(2),180-209.

Arshanapalli, B. \&Doukas, J. (1993) International stock market linkages: evidence from the pre- and post-October 1987 period, Journal of Banking and Finance, 17, 193-208.

Cavoli, T., Rajan, R.S. \&Siregar, R. (2004) A survey of financial integration in East Asia: how far? How much further to go? Discussion Paper 0401, Center for International Economic Studies, University of Adelaide.

Click, R.W. \& Plummer, M.G. (2005) Stock market integration in ASEAN after the Asian financial crisis, Journal of Asian Economics, 16, 5-28.

Daly, K.J. (2003) Southeast Asian stock market linkages: evidence from pre- and postOctober 1997, ASEAN Economic Bulletin, 20(1), 73-85.

Desai, M.A. \&Dharmapala, D. (2008) Taxes, dividends and international portfolio choice, $3^{\text {rd }}$ Annual Conference on Empirical Legal Studies Conference Paper.

Engle, E.F. \& Granger, C.W.J. (1987) Cointegration and error correction: representation, estimation and testing, Econometrica, 55, 251-276. 
Hsiao, C. (1979a) Autoregressive modelling of Canadian money and income data, Journal of American Statistical Association, 74, 553-560.

Hsiao, C. (1979b) Causality tests in econometrics, Journal of Economic Dynamics and Control, 1, 321-346.

Johansen, S. (1988) Statistical analysis of cointegration vectors, Journal of Economic Dynamics and Control,12, 231-254.

Levy, H. \&Sarnat, M. (1970) International diversification of investment portfolios, American Economic Review,60, 668-675.

Ng, H.N. (2002) Stock market linkages in South-East Asia, Asian Economic Journal, 16(4), 353-377.

Ng, S. \&Perron, P. (1995) Unit root tests in ARMA models with data-dependent methods for the selection of the truncation lag, Journal of American Statistical Association, 90, 268-281.

Rajan, R.G. \&Zingales, L. (1998) Financial dependence and growth, American Economic Review, 88(3), 559-586.

Torre, A., Gozzi, J.C. \&Schmukler, S.L. (2006) Stock market development under globalization: whither the gains from reforms? Journal of Banking and Finance, 31, 1731-1754. 


\section{TABLES}

Table 1: Summary Statistics.

\begin{tabular}{|c|c|c|c|c|c|c|c|}
\hline Equity Market/Block & Mean & $\begin{array}{c}\text { Standard } \\
\text { Deviation }\end{array}$ & Minimum & Maximum & Median & Skewness & Kurtosis \\
\hline \multicolumn{8}{|c|}{ Panel A: Individual Emerging Equity Markets and Emerging Markets Block } \\
\hline China & $859,339.9$ & $783,987.2$ & $362,637.0$ & $3,739,097$ & $503,104.5$ & 2.069262 & 6.307563 \\
\hline Indonesia & $94,100.60$ & $38,718.32$ & $46,727.96$ & $201,433.1$ & $79,567.71$ & 0.905176 & 2.841049 \\
\hline Korea & $606,256.1$ & $247,202.1$ & $282,619.5$ & $1,195,187$ & $573,325.7$ & 0.506756 & 2.310217 \\
\hline Malaysia & $202,021.2$ & $44,775.00$ & $144,713.4$ & $312,584.9$ & $184,652.8$ & 1.286932 & 3.353484 \\
\hline Philippines & $44,928.59$ & $22,594.54$ & $21,239.22$ & $101,527.2$ & $35,818.50$ & 1.004048 & 2.811286 \\
\hline Taiwan & $526,593.3$ & $106,419.1$ & $380,495.5$ & $801,275.0$ & $499,750.6$ & 0.891024 & 2.986958 \\
\hline Thailand & $125,783.3$ & $28,291.05$ & $76,951.17$ & $214,648.2$ & $118,586.7$ & 1.095028 & 4.084578 \\
\hline EMB & $351,289.0$ & $173,431.7$ & $204,126.8$ & $935,103.0$ & $265,988.2$ & 1.718007 & 4.978653 \\
\hline \multicolumn{8}{|c|}{ Panel B: Individual Advanced Equity Markets and Advanced Markets Block } \\
\hline Japan & $4,176,392$ & $693,112.3$ & $2,883,982$ & $5,390,379$ & 422,8675 & -0.117703 & 1.531836 \\
\hline Hong Kong SAR & $1,175,104$ & $503,597.0$ & $608,095.5$ & $2,797,638$ & $966,881.2$ & 1.165813 & 3.646933 \\
\hline Australia & $741,406.9$ & $203,349.7$ & $466,074.2$ & $1,299,449$ & $682,914.7$ & 0.942433 & 2.986030 \\
\hline Singapore & $273,797.8$ & $100,422.8$ & $151,012.6$ & $53,9294.7$ & $237,627.9$ & 1.017398 & 2.929018 \\
\hline New Zealand & $37,819.85$ & $5,025.586$ & $26,802.48$ & $50,048.79$ & $38,014.25$ & 0.129995 & 2.469354 \\
\hline AMB & $1,280,904$ & $282,720.7$ & $84,3167.3$ & $1,889,271$ & $1,222,547$ & 0.283106 & 1.796165 \\
\hline
\end{tabular}

Notes:

1. The weekly SMC values are in US thousand dollars.

2. The EMB variable is computed as an average of the individual emerging markets within the Emerging Markets Block.

3. The AMB variable is computed as an average of the individual advanced markets within the Advanced Markets Block. 
Table 2: Augmented Dickey-Fuller (ADF) and Phillips-Perron (PP) Unit Root Tests - Level and First Difference of SMCs.

\begin{tabular}{|c|c|c|c|c|c|c|}
\hline \multirow[b]{2}{*}{ Equity Market/Block } & \multicolumn{3}{|c|}{ Level } & \multicolumn{3}{|c|}{ First Difference } \\
\hline & $\begin{array}{l}\text { Without } \\
\text { constant and } \\
\text { trend }\end{array}$ & $\begin{array}{l}\text { With } \\
\text { constant }\end{array}$ & $\begin{array}{l}\text { With constant } \\
\text { and trend }\end{array}$ & $\begin{array}{l}\text { Without constant } \\
\text { and trend }\end{array}$ & $\begin{array}{c}\text { With } \\
\text { constant }\end{array}$ & $\begin{array}{l}\text { With constant } \\
\text { and trend }\end{array}$ \\
\hline
\end{tabular}

Panel A: Individual Emerging Equity Markets within the Emerging Market Block

$\begin{array}{ccccccc}\text { China } & 0.130 & -1.128 & -0.426 & -13.951^{* * *} & -13.918^{* * *} & -14.084^{* * *} \\ & (0.127) & (-1.146) & (-0.451) & (-13.951)^{* * *} & (-13.918)^{* * *} & (-14.078)^{* * *} \\ \text { Indonesia } & 0.285 & -1.795 & -1.023 & -19.021^{* * *} & -18.983^{* * *} & -19.142^{* * *} \\ & (0.290) & (-1.816) & (-1.083) & (-19.426)^{* * *} & \left(-19.387^{* * *}\right) & (-19.908)^{* * *} \\ \text { Korea } & 0.341 & -2.176 & -1.887 & -17.056^{* * *} & -17.025^{* * *} & -17.111^{* * *} \\ & (0.356) & (-2.018) & (-1.581) & (-17.161)^{* * *} & (-17.142)^{* * *} & (-17.355)^{* * *} \\ \text { Malaysia } & 1.236 & -2.471 & -1.243 & -12.929^{* * *} & -12.967^{* * *} & -13.177^{* * *} \\ & (1.089) & (-2.410) & (-1.342) & (-12.945)^{* * *} & (-12.982)^{* * *} & (-13.177)^{* * *} \\ \text { Philippines } & 0.634 & -2.303 & -2.525 & -12.449^{* * *} & -12.443^{* * *} & -12.429^{* * *} \\ & (0.552) & (-2.233) & (-2.506) & (-12.451)^{* * *} & (-12.441)^{* * *} & (-12.425)^{* * *} \\ \text { Taiwan } & 0.567 & -1.637 & -1.210 & -14.736^{* * *} & -14.725^{* * *} & -14.781^{* * *} \\ & (0.570) & (-1.636) & (-1.211) & (-14.735)^{* * *} & (-14.725)^{* * *} & (-14.781)^{* * *} \\ \text { Thailand } & 0.904 & -2.267 & -1.322 & -14.779^{* * *} & -14.804^{* * *} & -15.134^{* * *} \\ & (0.889) & (-2.267) & (-1.282) & (-14.782)^{* * *} & (-14.806)^{* * *} & (-15.145)^{* * *}\end{array}$

Panel B: Individual Advanced Equity Markets within the Advanced Market Block

\begin{tabular}{ccccccc} 
Japan & 0.613 & -1.722 & -2.356 & $-16.295^{* * *}$ & $-16.292^{* * *}$ & $-16.259^{* * *}$ \\
Hong Kong SAR & $(0.668)$ & $(-1.663)$ & $(-2.205)$ & $(-16.307)^{* * *}$ & $(-16.272)^{* * *}$ & $(-16.243)^{* * *}$ \\
\multirow{2}{*}{ Australia } & 1.037 & -2.838 & -2.404 & $-12.665^{* * *}$ & $-12.682^{* * *}$ & $-12.779^{* * *}$ \\
& $(1.037)$ & $(-2.838)$ & $(-2.438)$ & $(-12.604)^{* * *}$ & $(-12.620)^{* * *}$ & $(-12.704)^{* * *}$ \\
& 1.064 & -2.029 & -1.387 & $-12.953^{* * *}$ & $-12.992^{* * *}$ & $-13.104^{* * *}$ \\
& $(1.064)$ & $(-2.035)$ & $(-1.464)$ & $(-12.977)^{* * *}$ & $(-13.011)^{* * *}$ & $(-13.083)^{* * *}$
\end{tabular}




\begin{tabular}{ccccccc} 
Singapore & 1.216 & -2.409 & -1.642 & $-14.146^{* * *}$ & $-14.213^{* * *}$ & $-14.391^{* * *}$ \\
\multirow{3}{*}{ New Zealand } & $(1.121)$ & $(-2.390)$ & $(-1.774)$ & $(-14.210)^{* * *}$ & $(-14.267)^{* * *}$ & $(-14.416)^{* * *}$ \\
& 0.953 & -2.390 & -1.694 & $-18.535^{* * *}$ & $-18.557^{* * *}$ & $-18.713^{* * *}$ \\
& $(0.924)$ & $(-2.310)$ & $(-1.692)$ & $(-18.586)^{* * *}$ & $(-18.825)^{* * *}$ & $(-19.303)^{* * *}$
\end{tabular}

Panel C: Emerging Market Block and Advanced Market Block

\begin{tabular}{|c|c|c|c|c|c|c|}
\hline EMB & $\begin{array}{c}3.877 \\
(4.056)\end{array}$ & $\begin{array}{c}3.162 \\
(3.346)\end{array}$ & $\begin{array}{c}0.675 \\
(0.728)\end{array}$ & $\begin{array}{c}-5.968^{* * *} \\
(-10.511)^{* * *}\end{array}$ & $\begin{array}{c}-11.043^{* * *} \\
(-11.083)^{* * *}\end{array}$ & $\begin{array}{c}-9.784^{* * *} \\
(-11.601)^{* * *}\end{array}$ \\
\hline AMB & 2.610 & $\begin{array}{c}-0.234 \\
(-0.508)\end{array}$ & $\begin{array}{l}-3.661^{* *} \\
(-3.320)\end{array}$ & $\begin{array}{c}-7.378^{* * *} \\
(-11181)^{* * *}\end{array}$ & $\begin{array}{l}-10.716^{* * *} \\
(-11379)^{* * *}\end{array}$ & $\begin{array}{l}-10.700^{* * *} \\
(-11351)^{* * *}\end{array}$ \\
\hline
\end{tabular}

Notes:

1. $\quad * * *$ denotes significance at 1 percent.

2. The critical values of the ADF and PP tests are based on MacKinnon (1996) one-sided $p$-value.

3. Figures in parentheses under the estimated values of ADF signify the estimated values of the corresponding PP test. 
Table 3: Evidence of Cointegrations between SMCs.

\begin{tabular}{|c|c|c|c|c|c|}
\hline \multicolumn{3}{|c|}{ Panel A } & \multicolumn{3}{|c|}{ Panel B } \\
\hline Dependent Variable & $\begin{array}{c}\text { Independent } \\
\text { Variable }\end{array}$ & $\begin{array}{c}\text { ADF test for error } \\
\text { term } \varepsilon_{1 t}\end{array}$ & Dependent Variable & $\begin{array}{c}\text { Independent } \\
\text { Variable }\end{array}$ & $\begin{array}{l}\text { ADF test for } \\
\text { error term } \varepsilon_{2 t}\end{array}$ \\
\hline AMB & EMB & $-10.97698^{* * *}$ & & & \\
\hline EMB & $\mathrm{MB}$ & $-10.44088^{* * *}$ & & & \\
\hline China & EMB & $-10.48966^{* * *}$ & China & AMB & $-10.52523^{* * *}$ \\
\hline EMB & China & $-10.80155^{* * *}$ & AMB & China & $-11.38939^{* * *}$ \\
\hline Korea & EMB & $-11.53484^{* * *}$ & Korea & AMB & $-10.71497^{* * *}$ \\
\hline EMB & Korea & $-10.97625^{* * *}$ & AMB & Korea & $-10.70644^{* * *}$ \\
\hline Taiwan & EMB & $-12.44908^{* * *}$ & Taiwan & AMB & $-11.80322^{* * *}$ \\
\hline EMB & Taiwan & $-11.88555^{* * *}$ & AMB & Taiwan & $-11.82253^{* * *}$ \\
\hline Malaysia & EMB & $-10.80441^{* * *}$ & Malaysia & AMB & $-11.25781^{* * *}$ \\
\hline EMB & Malaysia & $-11.07645^{* * *}$ & AMB & Malaysia & $-12.10385^{* * *}$ \\
\hline Hong Kong SAR & EMB & $-11.74802^{* * *}$ & Hong Kong SAR & AMB & $-10.89655^{* * *}$ \\
\hline EMB & Hong Kong SAR & $-11.54707^{* * *}$ & $\mathrm{AMB}$ & Hong Kong & $-11.26243^{* * *}$ \\
\hline Australia & EMB & $-11.7161^{* * *}$ & Australia & AMB & $-12.13906^{* * *}$ \\
\hline EMB & Australia & $-11.50786^{* * *}$ & AMB & Australia & $-12.51191^{* * *}$ \\
\hline Japan & EMB & $-11.07372^{* * *}$ & Japan & AMB & $-10.30662^{* * *}$ \\
\hline EMB & Japan & $-10.27571^{* * *}$ & AMB & Japan & $-10.03986^{* * *}$ \\
\hline Singapore & EMB & $-11.64643^{* * *}$ & Singapore & AMB & $-10.93365^{* * *}$ \\
\hline EMB & Singapore & $-11.93938^{* * *}$ & AMB & Singapore & $-11.77724^{* * *}$ \\
\hline
\end{tabular}




\begin{tabular}{|c|c|c|c|c|c|}
\hline Thailand & EMB & $-10.96524^{* * *}$ & Thailand & AMB & $-11.47755^{* * *}$ \\
\hline EMB & Thailand & $-11.38406^{* * *}$ & AMB & Thailand & $-12.49676^{* * *}$ \\
\hline Indonesia & EMB & $-10.95785^{* * *}$ & Indonesia & AMB & $-11.44084^{* * *}$ \\
\hline EMB & Indonesia & $-10.7926^{* * *}$ & AMB & Indonesia & $-11.8343^{* * *}$ \\
\hline New Zealand & EMB & $-12.08614^{* * *}$ & New Zealand & AMB & $-11.8394^{* * *}$ \\
\hline EMB & New Zealand & $-11.2854^{* * *}$ & AMB & New Zealand & $-11.60804^{* * *}$ \\
\hline Philippines & EMB & $-11.41276^{* * *}$ & Philippines & AMB & $-11.66571^{* * *}$ \\
\hline EMB & Philippines & $-10.75137^{* * *}$ & AMB & Philippines & $-11.55514^{* * *}$ \\
\hline
\end{tabular}


Table 4: Estimates of Error Correction Models against Emerging Market Block.

\begin{tabular}{|c|c|c|c|}
\hline Dependent Variable & Independent Variable & $\begin{array}{c}\text { Wald } F \text {-test } \\
(p \text {-value })\end{array}$ & $\begin{array}{c}\text { Speed of Adjustment } \\
\text { Coefficient } \\
\text { (p-value) }\end{array}$ \\
\hline
\end{tabular}

Panel A: Individual Emerging Equity Markets against Emerging Market Block

$\begin{array}{cc}\text { China } & \text { EMB } \\ & (2,6) \\ \text { EMB } & \text { China } \\ & (5,2) \\ & \text { EMB } \\ \text { Indonesia } & (2,1) \\ & \text { Indonesia } \\ \text { EMB } & (5,2) \\ & \text { EMB } \\ \text { Korea } & (4,1) \\ & \text { Korea } \\ \text { EMB } & (5,1) \\ & \\ \text { Malaysia } & \text { EMB } \\ & (4,4) \\ \text { EMB } & \text { Malaysia } \\ & (5,1) \\ \text { Philippines } & \text { EMB } \\ & (2,3) \\ \text { EMB } & \text { Philippines } \\ & (3,2) \\ \text { Taiwan } & \text { EMB }\end{array}$

$$
\begin{array}{cc}
19.70069^{* * *} & -0.779117^{* * *} \\
(0.0000) & (0.0000) \\
6.679414^{* *} & -0.251885 \\
(0.0105) & (0.1504) \\
& \\
6.443682^{* *} & -0.64234^{* * *} \\
(0.0119) & (0.0000) \\
9.116705^{* * *} & -0.485543^{* *} \\
(0.0029) & (0.0008) \\
& \\
5.149842^{* *} & -0.363091^{* *} \\
(0.0243) & (0.0236) \\
0.115936 & -0.485083^{* *} \\
(0.7338) & (0.0003) \\
& \\
11.25897^{* * *} & -0.843909^{* * *} \\
(0.0009) & (0.0000) \\
4.515803^{* *} & -0.337252^{* *} \\
(0.0348) & (0.0129) \\
& \\
15.05381^{* * *} & -0.772915^{* * *} \\
(0.0001) & (0.0000) \\
4.52804^{* *} & -0.481801^{* *} \\
(0.0345) & (0.0001) \\
& \\
36.05928^{* * *} & -0.61523^{* * *}
\end{array}
$$$$
\text { 6.679414** }-0.251885
$$$$
-0.64234^{* * *}
$$$$
(0.0000)
$$$$
-0.485543^{* * *}
$$$$
\text { (0.0008) }
$$$$
-0.363091^{* *}
$$$$
\text { (0.0236) }
$$$$
-0.485083^{* * *}
$$$$
\text { (0.0003) }
$$

$-0.843909^{* * *}$$$
\text { (0.0000) }
$$$$
-0.337252^{* *}
$$$$
\text { (0.0129) }
$$

$-0.772915^{* * *}$

(0.0000)

$-0.481801^{* * *}$

(0.0001)

$-0.61523^{* * *}$ 


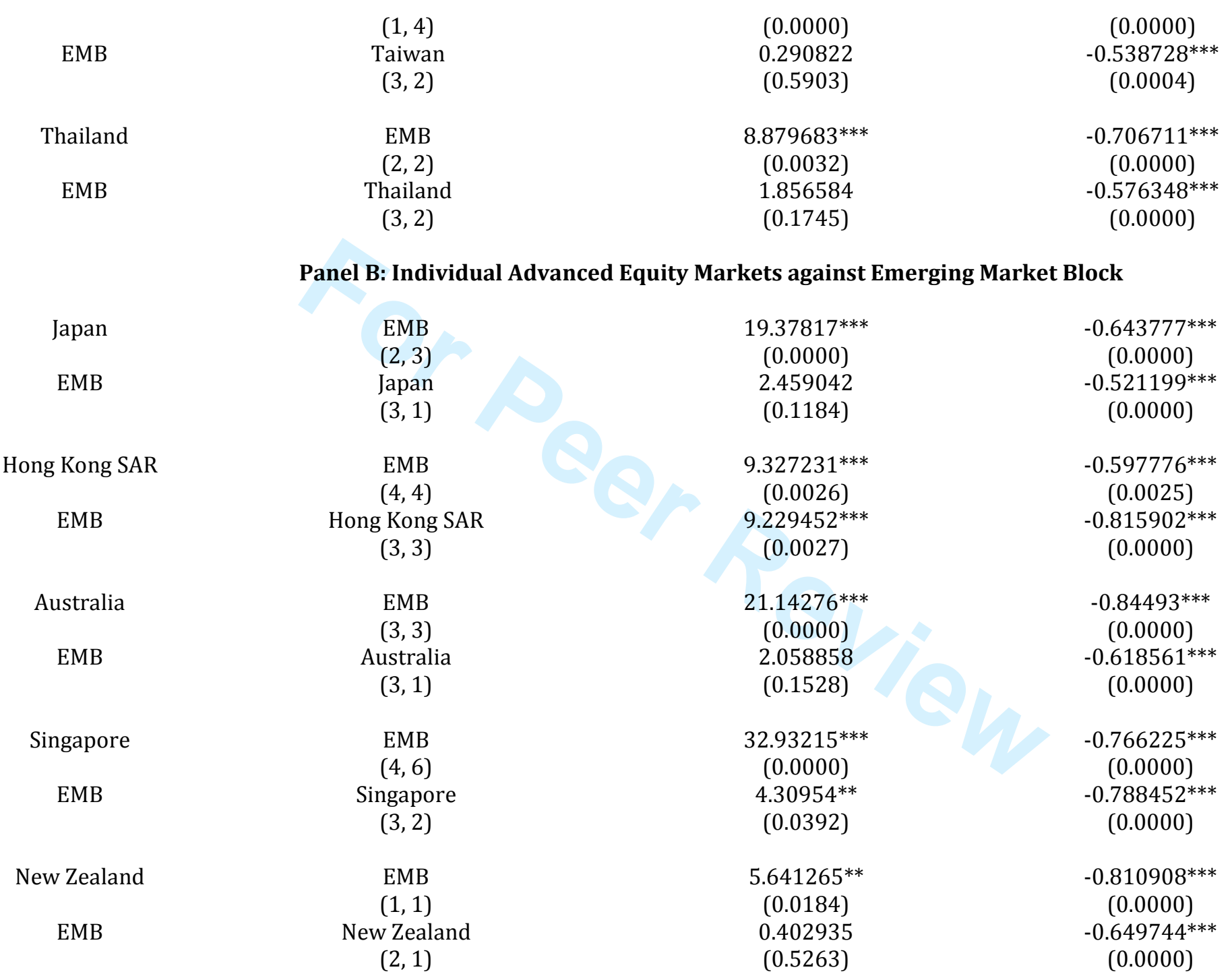




\section{Panel C: Advanced Markets Block against Emerging Markets Block}

$\begin{array}{cccc}\text { AMB } & \text { EMB } & 20.6137^{* * *} & -0.683884^{* * *} \\ & (4,3) & (0.0000) & (0.0001) \\ \text { EMB } & \text { AMB } & 4.302481^{* *} & -0.618691^{* * *} \\ & (3,2) & (0.0393) & (0.0000)\end{array}$

Notes:

1. $\quad{ }^{* * *}$ denotes significance at 1 percent; ${ }^{* *}$ denotes significance at 5 percent; $*$ denotes significance at 10 percent.

2. $\quad$ Figures in parentheses under the independent variables signify the number of lags $p$ and $q$ which minimizes the AIC.

3. The $F$-values in column 3 denotes the Wald test of restricted model where all lagged independent terms are equal to zero under the null hypothesis. The $p$-values are in parentheses.

4. The speed of adjustment coefficients are reported along with their respective $p$-values. 
Table 5: Estimates of the Error Correction Models against Advanced Market Block.

\begin{tabular}{|c|c|c|c|}
\hline Dependent Variable & Independent Variable & $\begin{array}{c}\text { Wald } F \text {-test } \\
(p \text {-value })\end{array}$ & $\begin{array}{c}\text { Speed of Adjustment Co } \\
\text { ( } p \text {-value) }\end{array}$ \\
\hline \multicolumn{4}{|c|}{ Panel A: Individual Emerging Equity Markets against Advanced Market Block } \\
\hline China & $\begin{array}{l}\text { AMB } \\
(2,1)\end{array}$ & $\begin{array}{l}0.096184 \\
(0.7568)\end{array}$ & $\begin{array}{c}-0.563683^{* * *} \\
(0.0000)\end{array}$ \\
\hline AMB & $\begin{array}{l}\text { China } \\
(2,3)\end{array}$ & $\begin{array}{c}12.29548^{* * *} \\
(0.0006)\end{array}$ & $\begin{array}{c}-0.733785^{* * *} \\
(0.0000)\end{array}$ \\
\hline Indonesia & $\begin{array}{l}\mathrm{AMB} \\
(2,4)\end{array}$ & $\begin{array}{l}14.08945^{* * *} \\
(0.0002)\end{array}$ & $\begin{array}{c}-0.87125^{* * *} \\
(0.0000)\end{array}$ \\
\hline AMB & $\begin{array}{c}\text { Indonesia } \\
(3,2)\end{array}$ & $\begin{array}{l}16.13188^{* * *} \\
(0.0001)\end{array}$ & $\begin{array}{c}-0.716338^{* * *} \\
(0.0000)\end{array}$ \\
\hline Korea & $\begin{array}{l}\text { AMB } \\
(3,2)\end{array}$ & $\begin{array}{l}13.84236^{* * *} \\
(0.0003)\end{array}$ & $\begin{array}{l}-0.737018^{* * *} \\
(0.0000)\end{array}$ \\
\hline AMB & $\begin{array}{l}\text { Korea } \\
(4,1)\end{array}$ & $\begin{array}{c}3.773704^{*} \\
(0.0534)\end{array}$ & $\begin{array}{c}-0.407259^{* *} \\
(0.0105)\end{array}$ \\
\hline Malaysia & $\begin{array}{l}\text { AMB } \\
(3,2)\end{array}$ & $\begin{array}{l}5.495756^{* *} \\
(0.0200)\end{array}$ & $\begin{array}{l}-0.728974^{* * *} \\
(0.0000)\end{array}$ \\
\hline AMB & $\begin{array}{c}\text { Malaysia } \\
(3,3)\end{array}$ & $\begin{array}{l}17.29416^{* * *} \\
(0.0000)\end{array}$ & $\begin{array}{c}-0.755547^{* * *} \\
(0.0000)\end{array}$ \\
\hline Philippines & $\begin{array}{l}\text { AMB } \\
(2,1)\end{array}$ & $\begin{array}{l}1.541935 \\
(0.2157)\end{array}$ & $\begin{array}{c}-0.729709^{* * *} \\
(0.0000)\end{array}$ \\
\hline AMB & $\begin{array}{c}\text { Philippines } \\
(3,3)\end{array}$ & $\begin{array}{c}23.98597^{* * *} \\
(0.0000)\end{array}$ & $\begin{array}{c}-0.719533^{* * *} \\
(0.0000)\end{array}$ \\
\hline Taiwan & $\begin{array}{l}\text { AMB } \\
(1,2)\end{array}$ & $\begin{array}{l}13.26778^{* * *} \\
(0.0003)\end{array}$ & $\begin{array}{c}-0.801936^{* * *} \\
(0.0000)\end{array}$ \\
\hline AMB & $\begin{array}{c}\text { Taiwan } \\
(3,1)\end{array}$ & $\begin{array}{c}9.762198^{* * *} \\
(0.002)\end{array}$ & $\begin{array}{c}-0.687157^{* * *} \\
(0.0000)\end{array}$ \\
\hline Thailand & $\begin{array}{l}\text { AMB } \\
(2,2)\end{array}$ & $\begin{array}{c}10.0047^{* * *} \\
(0.0018)\end{array}$ & $\begin{array}{c}-0.84583^{* * *} \\
(0.0000)\end{array}$ \\
\hline AMB & $\begin{array}{c}\text { Thailand } \\
(2,2)\end{array}$ & $\begin{array}{l}7.210975^{* * *} \\
(0.0078)\end{array}$ & $\begin{array}{l}-0.817329^{* * *} \\
(0.0000)\end{array}$ \\
\hline
\end{tabular}


Panel B: Individual Advanced Equity Markets against Advanced Market Block

\begin{tabular}{|c|c|c|c|c|}
\hline \multirow{2}{*}{\multicolumn{2}{|c|}{ Japan }} & AMB & 3.098978* & $-0.709438^{* *}$ \\
\hline & & $(4,2)$ & $(0.0799)$ & $(0.0295)$ \\
\hline \multirow{2}{*}{\multicolumn{2}{|c|}{ AMB }} & Japan & 0.71199 & -0.167401 \\
\hline & & $(4,1)$ & $(0.3998)$ & $(0.5740)$ \\
\hline \multirow{2}{*}{\multicolumn{2}{|c|}{ Hong Kong SAR }} & AMB & 2.705466 & $-0.545825^{* * *}$ \\
\hline & & $(3,2)$ & $(0.1015)$ & $(0.0004)$ \\
\hline \multicolumn{2}{|r|}{ AMB } & $\begin{array}{c}\text { Hong Kong SAR } \\
(4,3)\end{array}$ & $\begin{array}{c}21.72249^{* * *} \\
(0.0000)\end{array}$ & $\begin{array}{c}-0.877174^{* * *} \\
(0.0000)\end{array}$ \\
\hline \multicolumn{2}{|r|}{ Australia } & $\begin{array}{l}\text { AMB } \\
(4,2)\end{array}$ & $\begin{array}{c}15.201^{* * *} \\
(0.0001)\end{array}$ & $\begin{array}{c}-0.704868^{* * *} \\
(0.0001)\end{array}$ \\
\hline \multicolumn{2}{|r|}{ AMB } & $\begin{array}{c}\text { Australia } \\
(3,3)\end{array}$ & $\begin{array}{c}7.741249 * * * \\
(0.0059)\end{array}$ & $\begin{array}{c}-0.931003^{* * *} \\
(0.0000)\end{array}$ \\
\hline \multicolumn{2}{|r|}{ Singapore } & $\begin{array}{l}\text { AMB } \\
(2,4)\end{array}$ & $\begin{array}{c}18.3439^{* * *} \\
(0.0000)\end{array}$ & $\begin{array}{c}-0.646834^{* * *} \\
(0.0000)\end{array}$ \\
\hline \multicolumn{2}{|r|}{ AMB } & $\begin{array}{c}\text { Singapore } \\
\quad(4,2)\end{array}$ & $\begin{array}{c}9.944836^{* * *} \\
(0.0019)\end{array}$ & $\begin{array}{c}-0.714413^{* * *} \\
(0.0000)\end{array}$ \\
\hline \multicolumn{2}{|r|}{ New Zealand } & $\begin{array}{l}\text { AMB } \\
(2,1)\end{array}$ & $\begin{array}{c}8.544757^{* * *} \\
(0.0039)\end{array}$ & $\begin{array}{c}-0.751229^{* * *} \\
(0.0000)\end{array}$ \\
\hline \multicolumn{2}{|r|}{ AMB } & $\begin{array}{c}\text { New Zealand } \\
(2,2)\end{array}$ & $\begin{array}{c}6.432093^{* *} \\
(0.0119)\end{array}$ & $\begin{array}{c}-0.798965^{* * *} \\
(0.0000)\end{array}$ \\
\hline \multicolumn{5}{|c|}{ Notes: } \\
\hline & \multicolumn{4}{|c|}{${ }^{* * *}$ denotes significance at 1 percent; ${ }^{* *}$ denotes significance at 5 percent; ${ }^{*}$ denotes significance at 10 percent. } \\
\hline 2. & \multicolumn{4}{|c|}{ Figures in parentheses under the independent variables are signifies the number of lags $p$ and $q$ which minimizes the AIC. } \\
\hline 3. & \multicolumn{4}{|c|}{$\begin{array}{l}\text { The } F \text {-values in column } 3 \text { denotes the Wald test of restricted model where all lagged independent terms are equal to zero under the null } \\
\text { hypothesis. The } p \text {-values are in parentheses. }\end{array}$} \\
\hline & \multicolumn{4}{|c|}{ The speed of adjustment coefficients are reported along with their respective $p$-values. } \\
\hline
\end{tabular}


Table 6: Leaders for Emerging and Advanced Market Blocks at 1 percent level of significance.

\begin{tabular}{|c|c|c|c|}
\hline Equity Market/Block & Attractor & Causality & Leading Equity \\
\hline \multicolumn{4}{|c|}{ Panel A: Individual Equity Emerging Markets against Emerging Markets Block } \\
\hline Developed and EMB & EMB & $\begin{array}{c}\text { Uni-directional } \\
\text { EMB } \rightarrow \text { Developed }\end{array}$ & No \\
\hline China and EMB & EMB & $\begin{array}{l}\text { Uni-directional } \\
\text { EMB } \rightarrow \text { China }\end{array}$ & No \\
\hline Indonesia and EMB & EMB & $\begin{array}{c}\text { Uni-directional } \\
\text { Indonesia } \rightarrow \text { EMB }\end{array}$ & No \\
\hline Korea and EMB & Korea & No causality & No \\
\hline Malaysia and EMB & EMB & $\begin{array}{l}\text { Uni-directional } \\
\text { EMB } \rightarrow \text { Malaysia }\end{array}$ & No \\
\hline Philippines and EMB & EMB & $\begin{array}{c}\text { Uni-directional } \\
\text { EMB } \rightarrow \text { Philippines }\end{array}$ & No \\
\hline Taiwan and EMB & EMB & $\begin{array}{l}\text { Uni-directional } \\
\mathrm{EMB} \rightarrow \text { Taiwan }\end{array}$ & No \\
\hline Thailand and EMB & EMB & $\begin{array}{l}\text { Uni-directional } \\
\mathrm{EMB} \rightarrow \text { Thailand }\end{array}$ & No \\
\hline Japan and EMB & EMB & $\begin{array}{l}\text { Uni-directional } \\
\text { EMB } \rightarrow \text { Japan }\end{array}$ & No \\
\hline Hong Kong SAR and EMB & Hong Kong SAR & $\begin{array}{c}\text { Bi-directional } \\
\text { Hong Kong } \leftrightarrow \text { EMB }\end{array}$ & Yes \\
\hline
\end{tabular}




\begin{tabular}{|c|c|c|c|}
\hline Australia and EMB & EMB & $\begin{array}{l}\text { Uni-directional } \\
\mathrm{EMB} \rightarrow \text { Australia }\end{array}$ & No \\
\hline Singapore and EMB & Singapore & $\begin{array}{l}\text { Uni-directional } \\
\text { EMB } \rightarrow \text { Singapore }\end{array}$ & No \\
\hline \multirow[t]{2}{*}{ New Zealand and EMB } & EMB & No causality & No \\
\hline & Panel B: Individual En & lity Markets against & lock \\
\hline China and AMB & China & $\begin{array}{l}\text { Uni-directional } \\
\text { China } \rightarrow \text { AMB }\end{array}$ & Yes \\
\hline Indonesia and $\mathrm{AMB}$ & AMB & $\begin{array}{c}\text { Bi-directional } \\
\text { Indonesia } \leftrightarrow \mathrm{AMB}\end{array}$ & No \\
\hline Korea and AMB & AMB & $\begin{array}{c}\text { Uni-directional } \\
\text { AMB } \rightarrow \text { Korea }\end{array}$ & No \\
\hline Malaysia and AMB & Malaysia & $\begin{array}{l}\text { Uni-directional } \\
\text { Malaysia } \rightarrow \text { AMB }\end{array}$ & No \\
\hline Philippines and AMB & AMB & $\begin{array}{c}\text { Uni-directional } \\
\text { Philippines } \rightarrow \text { AMB }\end{array}$ & No \\
\hline Taiwan and AMB & AMB & $\begin{array}{l}\text { Bi-directional } \\
\text { Taiwan } \leftrightarrow \text { AMB }\end{array}$ & No \\
\hline Thailand and AMB & AMB & $\begin{array}{l}\text { Bi-directional } \\
\text { Thailand } \leftrightarrow \text { AMB }\end{array}$ & No \\
\hline Japan and AMB & AMB & No causality & No \\
\hline Hong Kong SAR and AMB & Hong Kong SAR & Uni-directional & Yes \\
\hline
\end{tabular}


Hong Kong $\rightarrow$ AMB

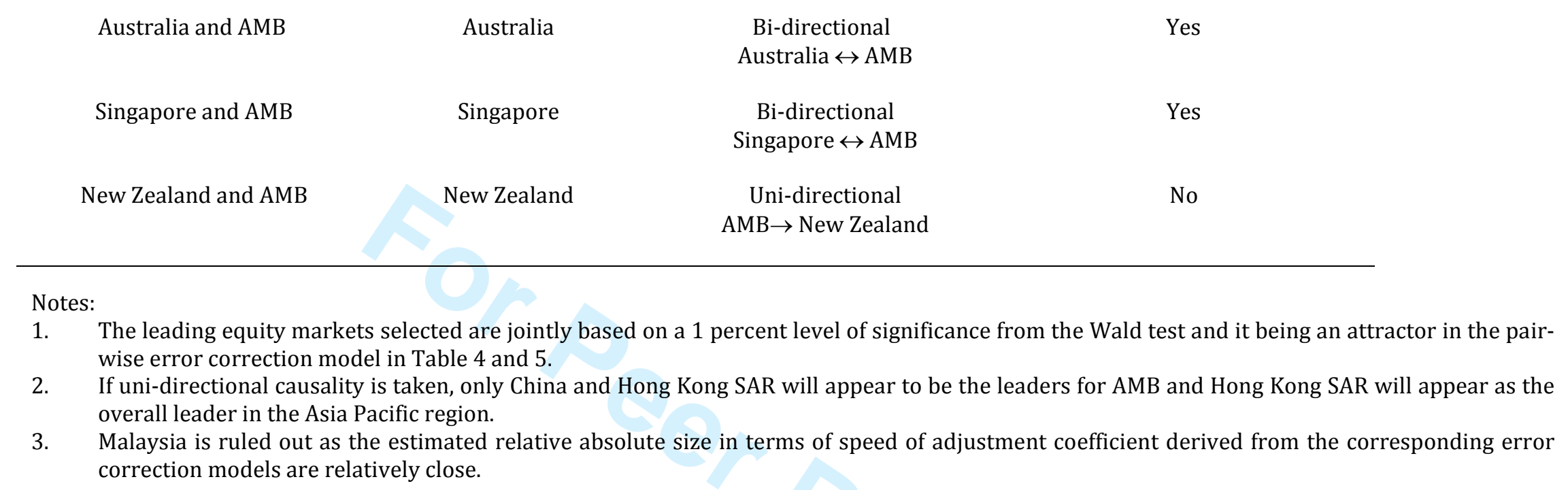

